\title{
A social constructed human beeing: a (bio)technological approach
}

\section{Un ser humano construído socialmente: una aproximación (bio)tecnológica}

\author{
Francesca Randazzo*; Juan R. Coca**; Jesús A. Valero Matas**
}

*Universidad de Santiago de Compostela; ${ }^{* *}$ Universidad de Valladolid

francescahonduras@yahoo.com

\begin{abstract}
As a social construction, (bio)technology ${ }^{1}$ should not be studied out of the social field. From a Social Imaginaries approach, (bio)technology can be considered as a contemporary social magma formed by biological, technical, psychological, sociological and axiological factors. Orbiting around the the cyborg metaphor, in this article we intend to build a multidisciplinary approach of this polycontexture.
\end{abstract}

Keywords:

(Bio)technology

Cyborg, Social

Imaginaries,

\section{Resumen}

Como una construcción social, la (bio)tecnología no debe ser estudiada fuera del campo social. Desde una perspectiva analítica sobre los imaginarios sociales, la (bio)tecnología puede ser considerada como un magma social formado por factores biológicos, técnicos, psicológicos, sociológicos y axiológicos. Orbitando alrededor de la metáfora del cyborg, en este artículo nos proponemos construir un enfoque multidisciplinar de esta polycontextura.

Palabras clave: Cyborg, Imaginarios sociales,
(Bio)tecnología

\section{Introduction}

It is not necessary to refer to scholars to affirm that western civilization tends to make a parallel between human and technological development. For Marxism it is even a nuclear concept to understand societies, their history and economy. The expression of this particular relation has, nowadays, pretty particular forms, and we will focus on this article on (bio)technology, conscious that we are assuming quite a challenge: the 'sociological study of technology' is far beyond being an evident matter, and it has been affirmed (Law, 2003) that there is not a single sociological study of technology at all ${ }^{2}$.

\footnotetext{
${ }^{1}$ Biotechnology is a "group of techniques which make possible the use of properties from living creatures to produce goods and services" (Muñoz, 2001, p. 11). That is, a technology with a strong productive and economical purpose. Whereas, (bio)technology refers to the technologies linked to the living in a global sense and, therefore, to those closely linked to the human being and his transformation. For this reason, (bio)technology is not circumscribed to the attainment of goods and services; the transformation itself of our body can be included in this concept. For instance, genetic engineering is not considered as part of biotechnology, in spite of the clear, deep and technological change of life it implies.

${ }^{2}$ In terms of society-biotechnology relations, it would be interesting to have something else than just satisfactory, ambivalent or controversial (cf. Muñoz, 2001).
} 
It is probably too soon to measure the influence of modern (bio)technology ${ }^{3}$ in the processes of identity, personal and collective building (Broncano, 2006, p. 24). Although, what is already common, is to find factual studies about ageing and how to minimize its effects; researches on new technologies capable of making up for physical disabilities (cochlear implants, pacemakers, orthopaedics, etc); advances with stem cells for a "reconstruction" of any kind of damage or pathology; improvements of the procedures and the achievement of materials in plastic surgery, just to mention some.

On the light of scientific achievement and prospective, can we refrain from seeing hybrids everywhere? They can be found in all sort of industries: medical, biotechnologyical, pharmaceutical, aesthetical,... Is this phenomenon showing something new about human societies? What are we becoming? Are humans becoming something better, worst or just different? It is much of evidence that we are witnessing the dissolution of some traditional distinctions like human/non-human, natural/artificial, culture/technology, theory/praxis, content/context, macro/micro (cf. Broncano, 2006 p. 26).

Gandy (2005) had developed a relational and materially grounded reading of the cyborg, as an intrinsic dimension to the co-evolution of social and technological systems. In his work he uses the cyborg metaphor as an abstract and inter-subjective realm through which political and cultural ideas become constituted or 'fleshed out'. The use of such a metaphor points to the interaction between social and biophysical processes; explores the interface between technology and the body; destabilizes the pervasive narratives of dematerialization, spatial malleability and virtualization; becomes, finally, a critical intellectual concept that challenges disembodied, dualistic, masculinist and teleological bodies of knowledge.

A cyborg is a hybrid creature, composed of organism and machine. But, cyborgs are compounded of special kinds of machines and special kinds of organisms appropriate to the late twentieth century. Cyborgs are post-Second World War hybrid entities made of, first, ourselves and other organic creatures in our unchosen "high-technological" guise as information systems, texts, and ergonomically controlled labouring, desiring, and reproducing systems. The second essential ingredient in cyborgs is machines in their guise, also, as communications systems, texts, and self-acting, ergonomically designed apparatuses (Haraway, 1991, p. 1).

Thinking the human being as a cyborg, implies first -for this article interest- a (bio)technological consideration, but -most important- it permits the confluence of many fields. Aspects such as ethics, politics and anthropology orbit around the possibilities of human self-transformation. In fact, the cyborg metaphor becomes a symbol for the militarization of society (Gandy, 2005; Gray 1997 and Der Derian, 2001). Through the Social Imaginaries (SI) theories, the role of this social construct into the social system can be studied, -for example, in the main processes of constitution of welfare, youth and modern nihilism.

Nevertheless, such a study is not obvious. Cultural meaning fades from collective consciousness, gradually disappearing from view as part of the 'taken-for-granted' world of everyday life. Questions about theories and methodologies make it, in the best of the cases, a new field of research. At any rate, the strict logics of reason does not lead studies to a conclusive and firm port, and most of the work on SI

\footnotetext{
${ }^{3}$ There is a confusion regarding the concept of biotechnology. In this paper, we will only consider the stage of New Biotechnologies which opens the possibility to transform the genome, as well as other technologies aimed to transform the human being, shaping an imaginary of self-construction of nature and of ourselves.
} 
have a great debt with literature, linguistics, and specially with hermeneutics. Is it possible to determine the schemes of thought that sustains the Social Imaginary of the human being?

\section{Disassembling and reassembling different bodies of knowledge}

When entering into the social analysis of technology, we should ask ourselves if we are not simply rediscovering, or re-articulating, what is already clear in the practice. John Law (2003) invites researchers and scholars to see how the technical field is always juxtaposed, if not mixed up, with political, legal, and economics.

For instance, internet is said to be one of the best communication, information and, even, emancipation tools, but the relevance given to communication in the contemporary society, beyond the rising importance of mass media, is a "consequence of a symbolic array interweaving communication, technology and future and has its conceptual origin in cybernetics and the political reorganization of mercantile and managerial mentality" (Cabrera, 2006 pp. 139 and f.).

It is hard to deny that we live under a new (bio)technological paradigm where the human selftransformation acquires an unusual importance. New sources of energy, the synthesis of new materials, laser technology or biotechnology in every social activity, cannot be out of an impact with notorious repercussions on the society (Quintanilla, 2005 \& Woolgar, 1988). The natural system is "machinized" and the artificial environment becomes immaterial (computer networks, cyberspace, virtual reality, etc.) (Hottois, 1999/2003).

Although, the perception of biotechnology ${ }^{4}$ is closely linked to its stages of experimental progress:

Biotechnology has experienced different stages, depending on the degree of manipulation of the organisms used and of the products obtained. Classic technology designs the empirical technologies aiming, basically to obtain food (bread, beer, cheese, wine, etc.). Later, appeared a number of Technologies to obtain specific products, such as amino acids, methanol, ethanol and, above all, antibiotics, through the selection of natural organisms able to produce these compounds in their fermentative processes, or to secrete these important secondary metabolites. Theses technologies have been designated as modern biotechnologies. The present stage of New Biotechnologies is characterized by the possibility to modify the genome of human beings (Montoya and Murillo, 1991, p. 191).

Jeremy Rifkin (1999) talks about the century of biotechnology characterized by the activity based on first, isolate, identify and recombine genes as the material of future economic activity; second, commercialization, patents, genetic engineering; third, globalization, power and biotic resources of the planet; forth, possibility of a eugenic civilization driven by economy; fifth, new scientific research about the genetic basis of behaviour; sixth, computer and telematic means; seventh, new ideas about nature to legitimize the century of biotechnology. To be able to put together such factors and make them work, we need a special tool if not to build this construct up, at least to think about it; hence,

\footnotetext{
${ }^{4}$ See note 1.
} 
[the] cyborg would be the central figure of our space-time, where the main rules of interpretation, assessment and localization interweave and become more visible [...] at least, regarding the social agent. In this sense, the cyborg would be the figure which ties the main arguments or subjects of our stories of identity and allows materializing, personifying or seeing the events, tensions and conditions which outline nowadays the eventual social agents (García Selgas, 1999, p. 185).

The cyborg is a sophisticated creation that simultaneously extends and threatens our understanding of what it means to be human (Figueroa \& Steven, 2002). It points on becoming 'post human' in order to liberate the human body from the illusory boundaries of the autonomous self (Gandy, 2005). Beyond fantastical combinations of bodies and machines, it is a way of thinking the world. Since the mid-1980s, it has been used as an ontological strategy to think about what appears to reside outside conventional frameworks of understanding.

The cyborg is a cybernetic organism that disassembles and reassembles, at the same time, chimera and social reality. Haraway (1991) is the first to use the cyborg as a metaphor to understand and communicate women's struggle:

A cyborg is a cybernetic organism, a hybrid of machine and organism, a creature of social reality as well as a creature of fiction. Social reality is lived social relations, our most important political construction, a world-changing fiction. The international women's movements have constructed 'women's experience', as well as uncovered or discovered this crucial collective object. This experience is a fiction and fact of the most crucial, political kind. Liberation rests on the construction of the consciousness, the imaginative apprehension, of oppression, and so of possibility. The cyborg is a matter of fiction and lived experience that changes what counts as women's experience in the late twentieth century. This is a struggle over life and death, but the boundary between science fiction and social reality is an optical illusion. (Haraway, 1991, p. 149).

It is a pretty fertile exercise trying to make a dialogical reading of images in the discourse, looking for the schemes with which reality is apprehended and ordered. Such an activity is made on hopping to make this schemes become somehow visible. The metaphor as a main working tool becomes the guideline of a conceptual system which might not be obvious (cf. Lakoff and Johnson, 1980/1995). Metaphor is thought to be a poetic or rhetorical matter, but it is pervasive in everyday's life. Its domain is much beyond language; metaphors are blueprints of thought and action:

The concepts that govern our thought are not just matters of the intellect. They also govern our everyday functioning, down to the most mundane details. Our concepts structure what we perceive, how we get around in the world, and how we relate to other people. Our conceptual system thus plays a central role in defining our everyday realities. If we are right in suggesting that our conceptual system is largely metaphorical, then the way we thinks what we experience, and what we do every day is very much a matter of metaphor. (Lakoff \& Johnson, 1980/1995, p. 25).

Associating and comparing, the metaphor shows not only the analogy between two objects or ideas; it speaks of difference and also of resemblance. This unlocks the possibility to perceive abstract realities in 
a more concrete way; then, builds a relation between dissimilar realities; and finally, makes an opened encounter of otherwise unreachable meanings and prospective.

\section{The power of creation}

New skin, new arm, new born. Is this just another expression of modernity? Are we just having more of the same? Is the cyborg just a way to profane the traditional order? Well, 'humanity' and 'technology' were never as simple and monolithic as the larger commercial and media powers, as well as other theories, have us believed. In this sense, Fuchs (1995) suggests that the cyborg is defined by its own 'indeterminate self-identity'. Indeed, the cyborg further challenges the heterosexual reproductive narratives of humanism by presenting a body that is 'self-reproducing' but not reproductive, and threatening biological reproduction with mechanical reproduction (Fuchs, 1995). The fact that humankind has always lived in reciprocity with technologies and machines is Cooke's (2006) basic foundment for his "cyborg theory".

Even if change is always present in everyday's life -it is not even difficult to be perceived!-, we have got the feeling that we live into a reality that is always the same, where social relations and power remain in the hand of the same groups. We think we live in a sort of system exterior to us and that it is just the way things are. At the other side, the "we" referred are people with silicone in their breasts, hair extensions, hearing aids, IUDs, artificial nails, arterial implants, etc. Becoming what we are not -already-, is somehow possible.

This and other achievements in the (bio)technical field might be speaking of an ancient -almost archetypical- wish of becoming Gods, or at least our own creators. It might refer to the idea of our ephemeral civilization adorned with an echo of eternity. This new Faustic order is settled on the antagonism of values, where science comes to rescue a man that thinks to get rid of terror when there is nothing left unknown (Beriaín,1996, p. 51). The complexity that appeared to enlarge our choices and settle a new scale of possibilities might imprisons the human being inside his own creation.

The emerging 'cyborg theory', allows to work around the dominant ideology of the 'human', and there what truly matters is to acknowledge the place from which studies are performed. Law (2003) distinguishes the dualism in the actor network theory approach and, we should add, Luhmann's systemic theory. Studies tend to reproduce and help to perform a functional understanding of the relations between entities. Networks -and systemic theory - are hegemonic and help to perform it into being, adding strength to a functional version of relationality, as part of a coherent, ordering, logic of control (cf. Law, 2003).

An actor-network approach describes something as it is imagined by participants in terms of systems and relations, as it is pretty the way of thinking in vogue. But, it does not have to be that way. It is possible to imagine other logics which produce different kinds of politics, and different kinds of persons that are not subjugated to those logics of means and ends, projects and goals.

Law (2003) insists that we live in a post-disciplinary era and, that social science endeavours to look beyond disciplinary boundaries, where the social analysis of technology is no exception. Also Davis-Floyd and Dumit (1998) say that we are immersed in cyborgs; the saturate our language, our media, our technology, and our way of being. To do so, an interdisciplinary attitude would be needed and, in spite of 
this relatively new determination, it is not easy to find the way to make it work in social sciences. It shows to be, if not a real failure, a reason to redefine limits, build resistances, create new hybrids, or just point to the inability and inappropriateness of trying to put knowledge or different methods together. In a certain way, universities, publishers, and others, refuse to have social sciences cyborgs.

\section{A new metaphor for an old world}

The possibility of change is not only exterior, but it seems sometimes hard to visualize change in more subtle ways. Human beings -and social relations- are in constant change too. Talking about and dealing with feminism, racism, social exclusion was of the order of utopia, not so far a go in spaces where it seems to be forgotten, especially when locking at other places. As problematic eugenic and bioethical issues, there are some parts of this change that can be seen, and other that not, as a relevance-opacity code (cf. Pintos, 2001 a).

From the current social construction of technology, there can be seen a distinction between people and societies on the one hand, and the world of artefacts and the natural world, on the other hand. In this way of thought, the social and the technical are divided. But, if making a difference is a fundamental step to understand and apprehend our world, living into an era where "normal" distinctions are on crisis is also a determinant moment for new ways of approaching knowledge. It is the case of the cyborg, although there are many other powerful ideas -like the man of Turing, the network paradigm and the Dedalus paradigm 5 .

The way in which differences are drown is what the theory of Social Imaginaries calls "relevancies" and "opacities" (cf. Pintos, 2001a), not only as a procedure to determine and acknowledge where lights and shadows are placed -as if there was a hidden conscious beneath this process- but an inner not explicit "imaginary", responsible of making this difference something "normal". A binary way of thinking is a totally uncritical tool, if it does not take into account that differences are generated in the relations that produce them; they do not just exist in the order of things. The analyst's job is to explore those relations, and the question is how best we might erode those essential distinctions (Law, 2003).

The simultaneity interaction of material and imaginary perceptions is at the basis of the Social Imaginaries Theories $^{6}$, and when talking about the cyborg, it is hard not to make a parallel: blurring of boundaries between the concrete and the social complexities; distinction between mind and body and between the material and the virtual. Social reality is somehow a tangible entity but also a relational construct, and we cannot disentangle the one from the other.

For Juan Luis Pintos Social Imaginaries "are being" schemes socially built, which allow us to perceive, explain and intervene in what every differentiated system considers as real. These imaginaries operate

\footnotetext{
${ }^{5}$ Manuel Garrido, talks about the man of Turing, the network paradigm and Dedalus paradigm. The first one refers to the computing and communication world, pointing to the beginning of what it would be later known as Artificial Intelligence. Alan Turing (1912-1954), published in 1936 "On calculable numbers", a paper that theorizes about an eventual calculating machine. The second one, the network paradigm, signals machines which simulated "the behaviour of the introvert solipsist subject from the Cartesian philosophy" (Turing, 1936, cited by Garrido, 2007). Machines that could make marvellous calculations, but were unable to communicate among them, became able to maintain a flow of mutual information (Garrido, 2007: p. 874). The third one, the Dedalus paradigm, concerns the biological sciences and the implicit improvement and modification of the human being.

${ }^{6}$ The theory of social imaginaries has been developed during the last decades by thinkers of the stature of Cornelius Castoriadis, Michel Maffesoli, Josetxo Beriaín, Ángel E. Carretero, Juan Luís Pintos, Emmanuel Lizcano, Esther Díaz, Celso Sánchez Capdequí, Manuel Baeza, etc. (cf. Coca, 2008)
} 
as a metacode in the socially differentiated systems, inside a specific "mean" (money, belief, power, etc.) belonging to each system, through the relevance/opacity code and they generate forms and ways that act as realities. Furthermore, they have several functions, i.e., producing an image of stability in changing social relationships, generating perceptions of continuity in discontinuous experiences, providing global explanations of fragmentary phenomena and allowing intervention in processes built under the differentiated perspectives. Moreover, it can be said that they are built and rebuilt in three differentiated fields: in the differentiated specific system (politics, law, religion, science, etc.), in that of the organizations which make real the institutionalization of the system (governments, banks, churches, academies, etc) and in that of the interactions produced among individuals in the environment of the system. (cf. Pintos, 1995a; 1995b; 2001a; 2001b; 2003; 2004; 2005; 2006a; 2006b). Pintos suggests a list of procedures: criticism of the "facts", construction of "observables", establish first and second order observations, and the use of a relevance/opacity code based on semantic references.

In spite of the affectation of the definition, this is far from being a recipe to be followed and methods are not always explicit. In the best of the cases, analytical discourse techniques are lent from other fields and maybe not always acknowledged or treated as accurately as they should, lending conclusions to be very closely like mere opinions (cf. Randazzo, 2010).

Wider studies of biotechnological social imaginaries are necessary. For the moment, we can only stress that social sciences are depicting a scene where humanity is reflected in a peculiar way. That image configures our social reality too. Sometimes it is like the deforming mirrors at the circus, where some of us might get lost, trying to remember how we used to look like before getting in. The "traditional" human bio-psycho-socio-axiological polycontexture might be in a process of change towards a bio-technopsycho-socio-axiological polycontexture.

\section{Different versions intertwined}

It is of no use to ask ourselves about the SI of biotechnology, the most public face of the becomingscyborg around us, if we are not rising any serious questioning of the bio/techno relation and the overlapping with distinct fields:

No field within biology, when we think in the positive level (the level focused on the achievement of a singular product) implies a certain capacity of intervention. We manipulate genes now, but we will manipulate genomes, cells, embryos, organs. We are gaining access to the understanding of the basis of the human behaviour, but we will end up having a detailed map of the process of how the brain works when we generate feelings and of the higher categories of thought, including the process of taking decisions. We develop drugs, still rather generic; however, we will develop nanomachines or minimal cells able to head for "the problem in order to achieve a possible molecular solution" (Moya, 2007, p. 228).

Cooke (2006) wonders how can we speak of what is biological when patenting living entities or elements as 'inventions', and thus technologies. We might be forgotten that the technological is a human construct, but can also be considered non-human, as human is strictly biological and much more than it. Practices and processes of technoscience are not simply a biological matter, it is a question of political or economic 
use, elisions and boundaries, legal apparatus around human, machine, biology and technology (cf. Cooke, 2006).

The cyborg metaphor, as well as for $\mathrm{SI}$, it is at root both a materialist concept and an idealist construct, which is not inconsistent with neo-Marxian conceptions of relations between material and abstract, offering a sense of continuity in our critical appreciation of the intersection between different and often contradictory modernities (for cyborg cf. Gandy, 2005). The aim for using the cyborg metaphor is to get to something quite other to functionalism. We are trying to avoid drawing things together and order them into a single vision, goal-related network. The cyborg, is more than one but less than many, elements are joined and separated, there is unity and multiplicity, fractional and shifting coherences.

As Law (2003) questions, is our job as researchers to represent the world as it is? Are we really trying to discover something important about the structures of the sociotechnical (the truth)? Or less comforting, are we in the process of uncritically reproducing a dominant ideology in which the current orderings of the world represent themselves? As the child that needs to destroy the toy to understand it, we seem to be trying to find each of our divine secrets, and as soon we do so, the mystery suddenly become human, that is to say, our own creation.

On the one hand, we seem to live in a new era ruled by the possibilities of human change, at least physically. On the other hand, systemic theories of society -specially Luhmann's - are hiding the power of individuals and their possibilities of action and social change. There is a need of new semiotics, methods, and sensibilities to explore the human construction of reality and social relations. In fact, the women's body has become problematic for her seemed easier to shrug it off (Haraway, 1991). The cyborg is an invitation to re-write our social stories. But this perspective is also regarded as a dystopia and an aggressive neoliberal form (Salleh, 2009). This will not be our case. Re-shaping our bodies might be a way to make visible a part of what is changing in our minds.

We need to face a vital challenge to imagine progressive and creative forms of politics, ethics, aesthetics and enchantments that do not rest on essential distinctions between the human and the non human but are instead relational. As social researchers, Law (2003) stands that we can make a description of the way things are, or presuppose a set of assumptions about how relations are organized in terms of power, strength, plausibility... Innocently enough we're describing (right or wrong) the world and its relations or we are just telling stories about the world, bringing into being what we describe, while pushing others things out of being. We are making a difference.

The question is how to articulate the relations between different realities and different versions, and here the cyborg metaphor is of help. First it is a fleshy-machinic hybrid. Second, it is also a hybrid, a set of partial connections, between what is real and what might perhaps be performed into being - a feminist, non-racist, and non-violent, thinking and performing alternative, sensitive realities and Otherness, different visions, different realities, different truths, different subjectivities and different versions of the good - and constant displacements between these. This hybrid between science fact and science fiction, could be compared with the dialectics of Social Imaginaries and Social Reality.

Yet the Social Imaginaries Theories do not -for the moment- show how interdependencies of evolving structures are engendered and do not stress on relationships -maybe the predominant systemic approach has something to do with it. Researches able to integrate other approaches might be necessary. Raymond Williams (1977/1980), for example, develops the gramscian concept of hegemony and his 
structures of feeling as a category to study pre-structural changes into society are an interesting tool for social sciences that has not been used enough (cf. Randazzo, 2006). In the frame of thought that we are at this time concerned, analogical hermeneutics applied to techno-sciences is another option that has lately been explored (Coca, 2010).

\section{Conclusion}

The cyborg, in popular culture, it frequently appears as the much-maligned figure of 'technology out of control', while among academic theorists it heralds an era of emancipatory and transgressive posthuman subjectivity. What happens with $\mathrm{SI}$ is a bit similar, as they are sometimes focused as a dangerous tool to be theorized because it may fall into the hands of the "bad fellows", or as part of that indispensable move needed in social studies, which will brings back the option of hope and change. Some scholars (cf. Cooke, 2006; Law, 2003) seem to alert about the concept of the "human" as a semiotic category that serves a normative device, designed to weed out difference, specially because of its ability to incorporate new forms of being into its matrix; when to be 'human' is to understand and appreciate the mobilities of split vision, that is to recognize the privilege of partial perspectives, of balancing and relating different realities and versions intertwined. They may intersect but cannot be reduced to one another. Social Imaginaries might be under this same risk of being co-opted and loosing its potential and strength.

But as renegades in the halls of subjective power, the cyborg and the $\mathrm{SI}$ are also the unburied expectations in the Beck's society of risk. Fluid, changing, malleable, they remember that the "reality" we live in is just one possibility among others.

\section{Referencias}

Beriain, Josetxo (1996). La integración de las sociedades modernas. España: Anthropos.

Broncano, Fernando (2006). Entre ingenieros y ciudadanos. Filosofía de la técnica para días de democracia. Madrid: Montesinos.

Cabrera, Daniel H. (2006). Lo tecnológico y lo imaginario. Las nuevas tecnologías como creencias y esperanzas colectivas. Buenos Aires: Biblos.

Coca, Juan R. (2010). La compresión de la tecnociencia. Huelva: Editorial Hergué.

Coca, Juan R. (Ed.) (2008). Las posibilidades de lo imaginario. Barcelona: Ediciones Serbal.

Cooke, Grayson (2006). Human - 1 / Cyborg - 0: A Personal History of a Human-Machine Relation. Nebula, 3(1), 19-30.

Davis-Floyd, Robbie \& Dumit, Joseph (Eds.) (1998). Cyborg babies. New York: Routledge.

Der Derian, James (2001). Virtuous war: mapping the military-industrial-media-entertainment network. Boulder, CO.: Westview Press.

Figueroa, Heidi J. \& Steven, Mentor (2002). The cyborg handbook. New York: Routledge. 
Fuchs, Cynthia J. (1995). Death is Irrelevant. In Chris H. Gray, Heidi Figueroa-Sarriera, \& Steven Mentor (Eds.), The Cyborg Handbook (pp. 281-300). New York: Routledge.

Gandy, Matthew (2005). Cyborg Urbanization: Complexity and Monstrosity in the Contemporary City. International Journal of Urban and Regional Research, 29(1), 26-49.

García Selgas, Fernando J. (1999). El cyborg como reconstrucción del agente social. Política y Sociedad, 30, 165-191.

Garrido, Manuel (2007). La explosión de la tecnología: tres metáforas para el siglo XXI. In Manuel Garrido; Luis M. Valdés \& Llopis Arenas (Coords.), El legado filosófico y científico del siglo XX (pp. 867-886). Madrid: Cátedra.

Gray, Chris Hables (1997). The Cyborg soldier: future/present. In Chris H. Gray (Ed.), Postmodern war: the new politics of conflict (pp. 453-468). New York: Guilford Press.

Haraway, Donna J. (1991). Simians, Cyborgs and Women: The Reinvention of Nature. London: Routledge.

Hottois, Gilbert (1999/2003). Historia de la filosofía del renacimiento a la posmodernidad. Madrid: Cátedra.

Lakoff, George \& Johnson, Mark (1980/1995). Metáforas de la vida cotidiana. Madrid: Cátedra.

Law, John (2003). Networks, Relations, Cyborgs: on the Social Study of Technology. Lancaster: Centre for Science Studies, Lancaster University. Access December $12 \quad 2009$ at http://www.comp.lancs.ac.uk/sociology/papers/Law-Networks-Relations-Cyborgs.pdf, previously published at http://www.comp.lancs.ac.uk/sociology/soc042jl.html in 2000.

Montoya, E. \& Murillo, F. (1991). Biotecnología: perspectiva científica. In Roberto Dorado; Juan M. Rojo; Eugenio Triana \& Francisco Martínez, (Eds.), Ciencia, tecnología e industria en España (pp. 191-223). Madrid: Fundesco.

Moya, Andrés (2007). Hombres y cyborgs. Ludus Vitalis, XV(28), 227-230.

Muñoz, Emilio (2001). Biotecnología y sociedad. Encuentros y desencuentros. Madrid: Cambridge University Press-OEI.

Pintos, Juan Luis (1995a). Los imaginarios sociales. La nueva construcción de la realidad social. Bilbao: Instituto Fe y Secularidad/Sal Terrae.

Pintos, Juan Luis (1995b). Orden social e imaginarios sociales (Una propuesta de investigación). Papers, 45, 101-127.

Pintos, Juan Luis (2001a). Construyendo realidad(es): Ios Imaginarios Sociales. Realidad. Revista del Cono Sur de Psicología Social y Política, 1, 7-24.

Pintos, Juan Luis (2001b). Apuntes para un concepto operativo de Imaginarios Sociales. In Lyliam Alburquerque \& Rafael Iglesia (Eds.), Sobre los imaginarios urbanos (pp. 67-103). Buenos Aires: FADU-UBA. 
Pintos, Juan Luis (2003). El metacódigo relevancia/opacidad en la construcción sistémica de las realidades. RIPS (Revista de Investigaciones Políticas y Sociológicas), 2(1-2), 21-34.

Pintos, Juan Luis (2004). Inclusión/exclusión. Los Imaginarios Sociales de un proceso de construcción social. Sémata. Ciencias sociales y humanidades, 16, 17-52.

Pintos, Juan Luis (2005). Comunicación, construcción de la realidad e imaginarios sociales. Utopía y Praxis Latinoamericana, 10(29), 37-65.

Pintos, Juan Luis (2006a). Imaginarios y medios de comunicación. In Xan Bouzada Fernández (Coord.), Cultura e novas tecnoloxías (pp. 21-44). Santiago de Compostela: Consello da Cultura Galega.

Pintos, Juan Luis (2006b). Comunicación, construcción de realidad e imaginarios. In IECO (Coord.), Proyectar imaginarios (pp. 23-66). Bogotá: Instituto de Estudios en Comunicación y CulturaUniversidad Nacional de Colombia-Sociedad Cultural La Balsa.

Quintanilla, Miguel Ángel (2005). Tecnología: Un enfoque filosófico y otros ensayos de filosofía de la tecnología. México: FCE.

Randazzo, Francesca (2006). Honduras, Patria de la espera. Tegucigalpa: Instituto Hondureño de Antropología e Historia.

Randazzo, Francesca (2010). Imaginario social y crisis política en Honduras. Unpublished research. Universidad de Santiago de Compostela, Santiago de Compostela, Dept. Political Sciences.

Rifkin, James (1999). The biotech century: harnessing the gene and remaking the World. New York: Jeremy P. Tarcher/Putnam.

Salleh, A. (2009). The dystopia of technoscience: An ecofeminist critique of postmodern reason. Futures, 41(4), 201-209.

Williams, Raymond (1977/1980). Marxismo y literatura. Barcelona: Ediciones península.

Woolgar, Steven (1988). Science: The Very Idea. London: Routledge.

\section{Historia editorial}

Recibido: 15/11/2009

Primera revisión: 03/06/2010

Aceptado: 05/01/2011

\section{Formato de citación}

Randazzo, Francesca; Coca, Juan R. y Valero Matas, Jesús A. (2011). A social constructed human beeing: a (bio)technological approach. Athenea Digital, 11(2), 101-112. Disponible en http://psicologiasocial.uab.es/athenea/index.php/atheneaDigital/article/view/689 


Este texto está protegido por una licencia Creative Commons.
Usted es libre de copiar, distribuir y comunicar públicamente la obra bajo las siguientes condiciones:
Reconocimiento: Debe reconocer y citar al autor original.
No comercial. No puede utilizar esta obra para fines comerciales.
Sin obras derivadas. No se puede alterar, transformar, o generar una obra derivada a partir de esta obra.
Resumen de licencia - Texto completo de la licencia

